\title{
Correction to: Modelling the Stars of the Sagrada Familia
}

\author{
María de los Desamparados López de Briñas Ferragut ${ }^{1}$ (])
}

Published online: 8 June 2020

(c) Kim Williams Books, Turin 2020

\section{Correction to: Nexus Network Journal https://doi.org/10.1007/s00004-020-00488-y}

During production the name of the author was incorrectly written.

The original article has been corrected.

Publisher's Note Springer Nature remains neutral with regard to jurisdictional claims in published maps and institutional affiliations.

The original article can be found online at https://doi.org/10.1007/s00004-020-00488-y.

María de los Desamparados López de Briñas Ferragut mlope453@xtec.cat

1 Institut Josep Puig i Cadafalch (Josep Puig i Cadafalch High School), Carrer Sant Josep de Calassanç, 16, 08303 Mataró, Barcelona, Spain 